$>$ I denne spalten presenteres tidligere publiserte artikler, mange av dem fra Tidsskriftet.

Artiklene er utvalgt og blir introdusert av Ole Didrik Lærum.

\title{
Lytt til barna
}

\author{
Alle vet at kua har fire mager - eller rettere sagt én mage med fire rom, men at mennesket \\ besitter to mager, er dessverre ikke blitt allment kjent. Særlig har barna en egen dessert- \\ mage, uavhengig av om de har spist opp den øvrige maten eller ikke.
}

Barn kan være forbausende rasjonelle og kloke. De har også en viktig misjon ved å oppdra foreldrene. Særlig når et par har fått det første barnet, må de gjennomgå en bratt læringskurve som foreldre og oppdragere. Hvem skal lære dem det? Bøker og blader har lett for å være både banale og bedrevitende. Besteforeldre kan utløse aggresjon når de på nytt hever pekefingeren overfor barn og svigerbarn. Da står bare barnebarna deres igjen. Jeg tror ikke at småbarnsforeldre er helt klar over hvilken enorm jobb barna utfører for dem, og uten dem ville de ha gjort utrolig mange flere feil enn de allerede gjør.

Julen er spisetid. Mens mange strever med å holde kroppsvekten resten av året, lar de det bare stå til med storspising når denne høytiden starter for fullt. Men så kommer problemet: Barna har lett for å forsyne seg for mye av alle de lekre rettene. Til slutt sitter både barn og voksne og gisper av metthet, og barna etterlater seg tallerkener breddfulle av uspist mat. Da er det at de forlanger dessert. Ikke nok med det, de skal ha dessert flere ganger. De overmette voksne kommer med skjenneprekener, men det preller fullstendig av. Det hjelper ikke å snakke om fattige barn i utviklingsland, at man slett ikke har råd til å kaste god mat, eller at bankkontoen er tom.
Den er skrevet av to kloke og kunnskapsrike gastroenterologer. Arnold Berstad (f. 1940) var en av pionerene i norsk gastroenterologi. Etter mange år som professor i faget ved Haukeland universitetssykehus i Bergen er han nå emeritert og arbeider ved Lovisenberg Diakonale Sykehus i Oslo. Ved samme sykehus jobber Jørgen Valeur $50 \%$ som forsker og $50 \%$ som lege i spesialisering (LIS) i indremedisin. I 2010 tok han doktorgraden med en avhandling om matoverfølsomhet. Begge vet i høyeste grad hva de skriver om.

Når vi nå trykker denne artikkelen om igjen i Tidsskriftets julenummer, så er det i håp om at de voksne er ærlige nok til å formidle budskapet til sine håpefulle små: Vi - og særlig barna - har en egen dessertmage som er særlig aktiv i julehøytiden.

\section{Ole Didrik Lærum}

ole.laerum@gades.uib.no

Ole Didrik Lærum er professor (adj.) ved Københavns Universitet og professor emeritus ved Universitetet i Bergen.

\section{Dessertmage}

Berstad A, Valeur J. Dessertmage. Tidsskr Nor Legeforen 2011; 131: 2453-4.

Det kan være vanskelig å motstå desserten, selv om man egentlig er mett. Innsikt i magesekkens fysiologi kan belyse hvorfor vi gjerne synes at vi har litt ekstra plass til noe søtt.

«I can resist everything except temptation» (1)

Sult og metthet styres i utgangspunktet av mekanismer som ivaretar stabiliteten i kroppens indre miljø (2). Denne homøostatiske reguleringen kan imidlertid overstyres av lystrelaterte drivkrefter - såkalt hedoniske signaler (3). Slik modulering kommer i stand ved at hjernens belønningsbaner påvirker hypothalamus og kan kanskje forklare hvordan et «irrasjonelt» søtsug kan oppstå (4). Men hvordan får vi plass til dessert i magesekken når den allerede er full?
Normalt slapper magesekken av under et måltid slik at den kan ta i mot 300-400 ml uten at trykket øker. Denne vagovagale «akkommodasjonsrefleksen» ble beskrevet av Cannon \& Lieb allerede i 1911 (5), og når den fungerer som den skal, vil den øverste delen av magesekken (fundus- og corpusdelen) utvide seg og måltidet resultere i en behagelig metthetsfølelse (fig 1a). Ved stress, derimot, svekkes refleksen: Magesekken blir stivere og rommer mindre, og mye av måltidet legger seg lenger nede, i antrum. Man kjenner seg oppfylt og stinn - en ubehagelig metthetsfølelse (6) (fig 1b).
Med nyutviklet høyoppløselig manometri har gruppen til Jan Tack i Belgia vist at metthetsfølelse under et måltid i stor grad er en funksjon av trykket i magesekken (7). Hvis man spiser dessert etter at man egentlig føler seg mett, «lurer» man den normale metthetsfølelsen - glukose stimulerer nemlig akkommodasjonsrefleksen, trolig via vagale afferente nervefibre (8). Dessert vil på den måten kunne redusere trykket i magesekken og minke metthetsfølelsen. En søt dessert får altså magesekken til å romme mer, og vi kan spise litt til uten å oppleve ubehag. Dessertmage 


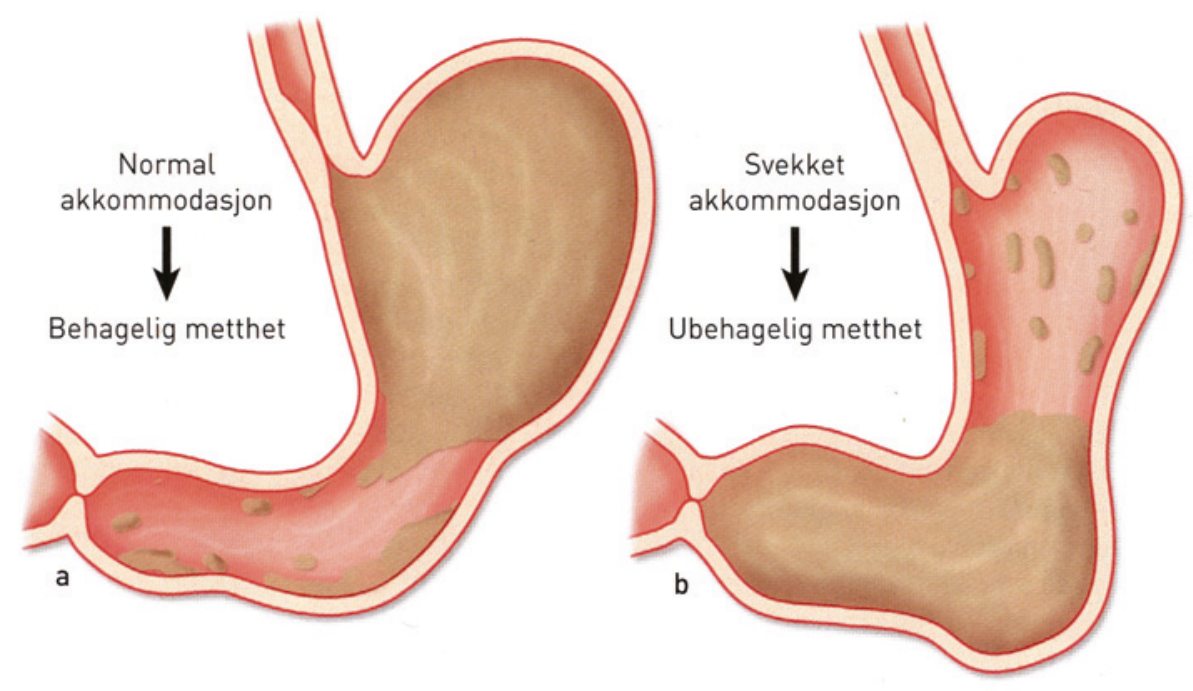

Figur 1 Magesekkens akkommodasjon og dens betydning for metthet. al Ved normal akkommodasjon relakseres den øverste delen av ventrikkelen via vagusnerven, og måltidet resulterer i en behagelig metthetsfølelse. b) Stress hemmer den vagale tonus og ventrikkelen blir stivere og tømmer seg dårligere, slik at trykket i magesekken øker og inntak av mat gir ubehag. Slik hemming av akkommodasjonsrefleksen er foreslått som mekanisme for symptomene ved funksjonell dyspepsi (6). En søt dessert vil stimulere akkommodasjonsrefleksen og gi behagelig metthet selv om magesekken er full. (c) Kari Toverud

handler derfor om kortvarig lettsinn med potensielt tunge konsekvenser.

Vagusnerven har både perifere og sentrale glukoreseptorer og modulerer via disse magesekkens funksjon på flere måter $(9$, 10). Ved operasjoner på magesekken, som for eksempel ved moderne fedmekirurgi, kan denne reguleringen bli forstyrret. Således reduseres magesekkens volum betyde- lig ved både gastrisk bypass og langsgående ventrikkelreseksjon (sleeve-gastrektomi), og akkommodasjonsrefleksen vil da trolig fungere dårlig. Hvis pylorusfunksjonen også ødelegges, som ved gastrisk bypass, kan sterk vagusstimulering på grunn av rask tømming av glukose til tynntarmen bidra til det såkalte dumpingsyndromet (11). Hos fedmeopererte gir søte måltider derfor ikke lenger behagelig metthet. Dessert kan tvert imot gi ubehag og dermed bidra til de jevnt over gode resultatene av fedmekirurgi (11).

\section{Arnold Berstad}

arnold.berstad@med.uib.no

Jørgen Valeur

Lovisenberg Diakonale Sykehus

\section{Litteratur}

1. Wilde 0 . Lady Windermere's fan. A play about a good woman. 28. utg. London: Methuen \& Co. Ltd. 1948: 13

2. Valeur J. Sult og metthet - en biologisk forklaringsmodell. Tidsskr Nor Lægeforen 2007; 127: 2546-8.

3. Lutter M, Nestler EJ. Homeostatic and hedonic signals interact in the regulation of food intake. J Nutr 2009; 139: 629-32.

4. Kenny PJ. Reward mechanisms in obesity: new insights and future directions. Neuron 2011; 69 : 664-79.

5. Cannon WB, Lieb CW. The receptive relaxation of the stomach. Am J Physiol 1911; 29: 267-73.

6. Berstad A. Functional dyspepsia - a conceptual framework. Gut 2000; 47 (suppl 4): iv3-4.

7. Janssen P, Vanden Berghe P, Verschueren S et al. Review article: the role of gastric motility in the control of food intake. Aliment Pharmacol Ther 2011; 33: 880-94.

8. Browning KN. Glucose and the vagus: sensory cells savour sweet substances. J Physiol 2010: 588: 749-50

9. Mei N. Vagal glucoreceptors in the small intestine of the cat. J Physiol 1978; 282: 485-506.

10. Wan S, Browning KN. D-glucose modulates synaptic transmission from the central terminals of vagal afferent fibers. Am J Physiol Gastrointest Liver Physiol 2008: 294: G757-63.

11. Hofs $\varnothing$ D, Aasheim ET, Søvik TT et al. Oppfølging etter fedmekirurgi. Tidsskr Nor Legeforen 2011 131: 1887-92.

Mottatt 5.9. 2011, første revisjon innsendt 16.10 2011, godkjent 10.11. 2011. Medisinsk redaktør

Anne Kveim Lie. 